\title{
Quality of Nursing Work Life in Subang Hospital Indonesia
}

\author{
Sri Sumartini*, Asih Purwandari Wahjoe Puspita, Tirta Adikusuma Suparto, Slamet Rohaedi, Anggun Permatasari \\ Prodi D3 Keperawatan, FPOK \\ Universitas Pendidikan Indonesia \\ Bandung, Indonesia \\ *srisumartini@upi.edu
}

\begin{abstract}
Quality of Nursing Work Life is a concept that describes perception of nurses to the fulfillment of necessary pass through work experience in organizations, until the purpose from quality of nursing work life can suitable with the management function for managing a superior human resources along with the worker who have their own personal satisfaction of their own fulfillment. The purpose of this research is to know the description about Quality of Nursing Work Life for the nurse at inpatient rooms at Subang Regional General Hospital Class B. This research is descriptive quantitative research using method with proportionate stratified random sampling and univariate analysis along with the 131 respondents. Respondents is a nurse's executor in inpatient rooms. Data analysis in this study using mean with mean 105. The results showed that the score value is 123.42. The conclusion of this study is the description of Quality of Nursing Work Life on nurses in Subang Regional General Hospital Class B is in good category. Recommendations in this research is a continuously human resources development about quality of nursing work life.
\end{abstract}

Keywords-quality of nursing work life; quality of work life; nurse; hospital

\section{INTRODUCTION}

The hospital is a health care institution that organizes personal health services in plenary by providing inpatient, outpatient and emergency department [1]. Nurses are a vital profession in the hospital where their profession provide health service for 24 hours. Act of the Republic Indonesia no. 38 of 2014 states that the nursing care is the type of professional services where it is an integral part of health care that is based on the science of nursing to be addressed to the individual, family, group, or community, whether healthy or sick [2].

Quality of nursing work life is an assessment of perception or nurse about all dimensions that affect the quality of working life and relate to their experience in working as well in order to achieve organizational goals [3,4]. There are four dimensions that affect the Quality of nursing work life, namely the dimensions of work/ home life, work design dimension, the dimension of work context, and the dimensions of the work world.

Winasih says that organizational culture affects the quality of nursing work life and influence the performance of nurses and significantly affect the job satisfaction of nurses that affect the performance of nurses [5]. Ace says that when the HOSPITAL create a conducive working life quality of the job satisfaction of nurses also tend to increase [6].

Sadat in Iran, in its research showed nurses with bachelor graduates have a low quality of work life [7]. Hamim et al., the better the quality of nursing work life then it will give a good impact on the nurse's work environment [8]. Meanwhile, according to research results Artha that there is a relationship between the Quality of nursing work life with patient satisfaction in hospitals [9]. Then the results of research conducted Dirdjo that, the quality of nursing work life satisfaction significantly associated with job satisfaction of nurses [10]. Komjakraphan in their research in Thailand, said that because of the quality of work life has an important impact on attracting and retaining employees [11]. Oyoh research results, which means they have not felt well-being at work [12].

Inpatient unit has three shift rotation that is morning, noon, and night different from outpatient room there is only one work shift. The nurse in the inpatient unit has up to 24 hours in providing health services and the implementation of nursing care provided in a comprehensive manner.

Results of research conducted by Romadhoni, the workload of nurses in the inpatient unit as a whole showed the workload heavier objective by category compared to the intensive care room [13]. In addition, according to the results of research conducted by Rihulay, a nurse in the inpatient room has a working stress level is higher than nurses in the emergency room (ER) [14]. Workload of nurses in the inpatient unit relative heavier because according PERMENKES 262 / VII / 1979 ideally a ratio of one to two patient beds is guarded by one nurse [15].

Regional General Hospital Class B District Subang government-owned hospitals Subang district administered by the District Government with the main service outpatient, inpatient, emergency room (ER), Intensive Care Unit, room service Neonatal Obstetric Essential/Emergency Comprehensive (PONEK), Installation of Central Surgical (IBS), and anesthesia.

In the preliminary study on the dimensions of Work Life / Home Life some nurses said that to organize in the workplace 
and homework depends on each individual. One speaker said that they could rely on a household.

The results of preliminary studies on the dimensions of the design work, the nurse said that cleaning service worker can help nurses work in the room. However, nurses complained that they perform non-nursing work such as matters relating to the administration. While the results of preliminary studies on the dimensions of the work context, nurses are not quite satisfied with the performance appraisal system of existing nurses.

Results of preliminary studies on the dimensions of the work world the nurse said that salary levels are still not enough and adequate. In addition, although there is an incentive, but it does not affect a large proportion of wage income nurse. The nurse said that there are considerable differences in the acceptance of wage employees with the status of Civil Servants (PNS) and contract employees. Not only that, the nurse felt wages earned in accordance with the performance has not been done. On the other hand, the nurse feels that there is still less perception of the patient's family/community towards the nursing profession. According to the nurses, some people / families of patients against medical personnel duties affect the public perception.

\section{METHOD}

The design used in this research is a quantitative descriptive. Where the research located at inpatient unit Class B Subang Regency Hospital, Sampling techniques to be used in the form of stratified random sampling technique and is taken in proportion to the total sample of 131 nurses inpatient unit. The instrument used was a questionnaire Brooks Quality of Nursing Work Life Questionnairewhich has been modified by Puspita [4]. Variable data processing using univariate analyzes using mean / mean, median.

\section{RESULTS}

Research conducted starting in the second week of May 2018 with the respondent amounted to 131 nurses in the inpatient unit by using stratified random sampling with proportional sampling. The research was conducted using questionnaires from Brooks which has been modified by Puspita with the validity and reliability of test results in the form of a Cronbach alpha $=0938$ [3,4]. The questionnaire consists of 42 statements with 38 of them are positive and four negative statements.

TABLE I. CHARACTERISTICS OF RESPONDENTS BASED ON FREQUENCY DISTRIBUTION

\begin{tabular}{|c|l|l|}
\hline variables & Frequency & Percentage (\%) \\
\hline Gender & 35 & \\
Man & 96 & 26.7 \\
woman & & 73.3 \\
\hline Age & 70 & \\
<30 years & 61 & 53.4 \\
> 30 years & & 46.4 \\
\hline Marital Status & 29 & \\
Single & 100 & 22.1 \\
Married & 2 & 76.3 \\
Widower widow & \multicolumn{2}{|}{} \\
\hline
\end{tabular}

Table 1. Cont.

\begin{tabular}{|c|c|c|}
\hline $\begin{array}{c}\text { Education } \\
\text { SPK / SPR } \\
\text { Diploma of Nursing } \\
\text { Bachelor of Nursing } \\
\text { (Nurses) } \\
\end{array}$ & $\begin{array}{l}0 \\
87 \\
44\end{array}$ & $\begin{array}{l}0 \\
66.4 \\
33.6\end{array}$ \\
\hline $\begin{array}{c}\text { Experience Working As a } \\
\text { Nurse } \\
<11 \text { years } \\
>11 \text { years } \\
\end{array}$ & $\begin{array}{l}100 \\
31\end{array}$ & $\begin{array}{l}76.3 \\
23.7\end{array}$ \\
\hline $\begin{array}{c}\text { Experience Working As a } \\
\text { Nurse } \\
\text { at the Class B Subang } \\
\text { Regency Hospital } \\
<11 \text { years } \\
>11 \text { years }\end{array}$ & $\begin{array}{l}105 \\
26\end{array}$ & $\begin{array}{l}80.2 \\
19.8\end{array}$ \\
\hline Total & 131 & 100 \\
\hline
\end{tabular}

Primary Data

Gender female dominated with a total of 96 people with a percentage of $73.3 \%$ and amounted to 35 men with a percentage of $26.7 \%$. Based on age, people with aged less than 30 years were disposed have a higher respondent. A total of 100 respondents from 131 respondents were married at the frequency of $76.3 \%$ results, 29 respondents were unmarried with a percentage of $22.1 \%$, and there were $2(1.5 \%)$ of the respondents who had been widower/widow. On the educational level, Diploma of Nursing have more results with the number of 87 respondents $(66.4 \%)$ compared to Bachelor of Nursing with the number of respondents $44(33.6 \%)$. The majority of nurses in hospitals Class B Subang Regency has experience working as a nurse for less than 11 years (76.3\%), but 31 respondents $(23.7 \%)$ of them have working experience of over 11 years. A total of $105(80.2 \%)$ of respondents have worked in hospitals Class B Subang district for less than 11 years, and 26 respondents $(19.8 \%)$ of them have been working for more than 11 years in hospitals Class B Subang district.

TABLE II. FREQUENCY DISTRIBUTION BASED QUALITY OF NURSING WORK LIFE FOUR DIMENSIONS

\begin{tabular}{|c|l|l|l|l|}
\hline $\begin{array}{c}\text { Variable / Sub } \\
\text { Variables }\end{array}$ & $\begin{array}{c}\text { Brooks } \\
\text { Range } \\
\text { Scale } \\
\text { Value }\end{array}$ & $\begin{array}{c}\text { Central } \\
\text { Value } \\
\text { Scale } \\
\text { Brooks }\end{array}$ & $\begin{array}{c}\text { Range of } \\
\text { Value } \\
\text { Research }\end{array}$ & $\begin{array}{c}\text { Central } \\
\text { Value } \\
\text { Research }\end{array}$ \\
\hline Overall QNWL & $42-168$ & 105 & $69-161$ & 123.42 \\
\hline $\begin{array}{c}\text { Dimensional } \\
\text { Work-life Home } \\
\text { Life }\end{array}$ & $7-28$ & 17.5 & $12-27$ & $20: 59$ \\
\hline $\begin{array}{c}\text { Work } \\
\text { dimensional } \\
\text { design }\end{array}$ & $10-40$ & 25 & $19-36$ & 7.29 \\
\hline $\begin{array}{c}\text { Work } \\
\text { dimensional } \\
\text { context }\end{array}$ & $20-80$ & 50 & $26-77$ & 59.45 \\
\hline $\begin{array}{c}\text { Dimensions } \\
\text { Work World }\end{array}$ & $5-20$ & 12.5 & $6-20$ & 13.85 \\
\hline
\end{tabular}

Primary Data

Table 2 of the frequency distribution data of Quality of nursing work life in getting the results of values and value ranges amid Quality of nursing work life in hospitals class B Subang district is higher than the median value QNWL Brooks Scale totaling 105 with the results of the value of 123.42. For the value ranges of the research stands at 69-161 from Brooks scale of 42-168. The minimum value on the Quality of nursing 
work life in nursing inpatient wards in hospitals Class B tends to be higher Subang District that is 69 where the minimum value of the scale Brooks is 42 . On the dimension of work life home life/work experience in a range of values results in that dimension is at number 12 to number 27, and the biggest median value stands at 20:59. The dimensions of work design/composition results of work of the range of values is 10 to 40 with a median value stood at 29.7. On the dimension of work context/practices influence the range of values stood at 26 to 77 with the results of the mid value 59.45. Recently Reviewed dimensional work world/effects of the social environment of the results for a range of values that are in the 6 to 20 with the results of the median value as much as 13.85 .

\section{DISCUSSION}

In addition to the total amount of more female respondents are higher than male respondents, the average value for the quality of work life also tend to be higher at 123.69. This consistent with the results of research conducted Suresh in Thiruvananthapuramm, Kerala and Prihastuty in which the gender factor has a significant effect $[16,17]$. With the results of women had a quality of work life better and be able to balance work with home life than male nurses. However, these studies are not consistent with research by Thakre to nurses in Shri, VasantraoNaik Government Medical College and Hospital, a tertiary health care institution of Yawatmal, Maharashtra where nurse-sex male has better the quality of work life because nursing women tend to participate more in activities that create stress such nurses involved as a board member in the Nursing Union, the pressure on their requests, and other possibilities that could affect the quality of working life [18].

A total of 70 people aged less than 30 years of quality work life lower at 122.7 rather than nurse with over 30 years of age as much as 61 respondents with the results of the mid value 124.16. In accordance with research Sadat in which the worker with an age range of 30-40 have a good quality of working life [7]. In addition, Purnomo nurses have the results obtained are under 30 years of age tend to have a low QWL nurse where a person's age will affect the readiness of serving patients in nursing services [19]. However, according to Agheli good QNWL contained in nurses under 25 years for unmarried or do not have children, so there is no interaction between work and home life [20]. Not only that, Prihastuty nurses aged less than 35 years old have high QNWL being able to balance work with home life [17].

Unmarried respondents had an average value of the quality of working life of 123.86 is higher than respondents who were married at 123.32. In line with research conducted Prihastuty that marital status, unmarried nurse has a high QNWL, are better able to balance work with home life than nurses who are married [17].

In the results showed that nurses with nursing diploma level of education have an average value higher at 123.92 instead of Bachelor of Nursing (nurses) with the average value of 122.43. According to research conducted by Prihastuty less educated nurses have a high QNWL, are better able to balance work life with home life than nurses who are highly educated [17]. Not only that, according to Moradi, QWL in nurses with lower education better than the nurses at the higher education level [21]. It is seen that nurses with higher education have a high enough imagination on their life, However, according to Thakre, the Quality of nursing work life with higher education has the quality of work life better than nurses with lower education [18].

On work experience, respondents who have work experience of more than 11 years had an average value of 125.77 higher than nurses with work experience less than 11 years to sail 122.84. Prihastuty based on years of service, a nurse who works with longer period have high QNWL, are better able to balance work with home life than a shorter working period [17]. So even according to Moradi and Thakre in which a person has more work experience have a better QWL [18,21].

Purnomo on research in MojokertoPacetSumberglagah Leprosy Hospital, QWL has a positive and significant effect on job satisfaction. This means that if QWL the better it will be more satisfied nurses. Social support affects the working pressure. Career opportunities and significant positive effect on the Quality of Work Life Career Demands means if the higher it is the better QWL. Sari, her research results showed no significant correlation between the quality work life of nurses with job satisfaction of nurses in inpatient hospitals AM Parikshit with the degree of significance of P-Value 0,004 smaller than the 0.05 alpha value of $\mathrm{r} 275$ to have a relationship in a positive direction [22]. In addition, the research results Kholik, to nurse the General Services Agency (BLUD) in Kajen Hospital at Pekalongan District, said that Quality of work life (QWL) positive and significant impact on job satisfaction, means improving the Quality of nursing work life will trigger an increase in their job satisfaction [23]. In addition, the quality of work life (QWL) positive and significant impact on organizational commitment, means the better the Quality of nursing work life BLUDs Kajen Hospital at Pekalongan District will increase their organizational commitment. According Samtica, Quality of work life (QWL) positive and significant impact on organizational commitment, means the better the Quality of nursing work life Public Service Agency (BLUD) Kajen Hospital at Pekalongan District will increase their organizational commitment [24]. Not only that, according to Reza Agheli et al., QNWL have a positive effect on organizational commitment [24]. Eren says that education levels affect the nurse's commitment to the institution [25].

Thus, it can be said that the quality of work life affects the job satisfaction of nurses, that hospitals need to pay attention and provide a good quality of working life, safe and conducive. In addition to job satisfaction, aspects of quality of work life also affect organizational commitment and employee turnover [19,20,22-24].

\section{CONCLUSION}

That showed the Quality of nursing work life in hospitals Class B Subang Regency is in good categories. In the four dimensions of Quality of nursing work life in hospitals Class B 
Subang district also obtained a higher yield than the value range and the midpoint scale Brooks.

The hospital is expected to undertake a program of sustainable management of human resources development on the quality of working life is experienced nurses to improved health care in hospitals Class B Subang regency and increase competence in human resource development.

\section{REFERENCES}

[1] Act of the Republic Indonesia No.44 about Hospital, 2009.

[2] Republic of Indonesia, Act No. 38 of 2014 About Nursing. Chapter I Article 1 Paragraph 3, chapter V Nursing Practice Second section: Duties and Authorities Article 29 paragraph 1. Jakarta, 2014.

[3] B. Brooks and M.A. Andehospitalon, "Defining Quality Of Nursing Work Life," Nursing Economics, vol. 23, no. 6, pp. 319-326, 2005.

[4] A.P.W. Puspita, F.S. Susilaningsih and I.S, "Influence of Demographic Factohospital To Quality Of Nursing Work Life (Qnwl) Nurse Hospital," Indonesian Journal of Nursing Education, vol. 3, no. 1, pp. 13-24, 2017

[5] R. Winasih, Nursalam and N. Dian, "Cultural Organizations And Quality Of Nursing Work Life and Job Satisfaction Performance Against Nurses in hospitals Dr. Soetomo," 2015 Nurses, vol. 10, no. 2, pp. 332$342,2017$.

[6] A. Ace, "Work Life Quality Impact on Job Satisfaction and Participation Bangkinang Hospital Nurses, Pekanbaru” Jom FISIP, vol. 4, no. 2, 2017.

[7] Z. Sadat, M.S. Aboutalebi and N.M. Alavi, "Quality Of Work Life And Its Related Factohospital: A Survey Of Nurses," Trauma Monthly, 2016.

[8] N. Hamim, T. Suwandi and A. Yusuf, "Caring Behaviors Nurse Based On Quality Of Nursing Work Life And Self-Concept In Nursing Nurses In Hospital," International Journal of Development Research (IJDR), vol. 5, no. 10, pp. 5803-5808, 2017.

[9] N.S. Artha, Quality of Work Life Nurses relationship (Quality Of The Patient Satisfaction In Indrasari Regional General Hospital Rengat. Medan: Faculty of Nursing, Univehospitality of North Sumatra, 2015.

[10] Dirdjo, M.M. Sari, W. Nur K, Alfitri, Q.U. Zahratul, "Relationship Spirituality and Quality of Work Life NursesNurses With Job Satisfaction patient wards of the District General Hospital Tenggarong Andi Muhammad Parikshit Tenggarong," Journal of Medical Sciences, vol. 5, 2017.

[11] P. Komjakraphan, K. Balthip and P. Jittanoon, "Quality Of Work Life Among Nurse Practitionehospital Working At Primary Care Setting In Thailand," pp. 98-105, 2017

[12] S.I. Oyoh, and K. Yudianto, "Quality of Work Life Nurses Health Center Pangandaran,” JKP, vol. 5, no. 3, 2017
[13] R.D. Romadhoni, "Workload Objective Force Nurse at the Hospita Inpatient Services, Surabaya," Journal of Health Administration Indonesia, vol. 4, no. 1, 2016.

[14] S.B. Rihulay, Perbedaan Tingkat Stres Kerja Perawat dan Perawat Unit Gawat Darurat di Rumah Sakit Panti Wilasa Citarum dan Runah Sakit Panti Wilasa dr. Cipto Semarang. PSIK FiKes Universitas Kristen Satya Wacana Salatiga, 2012.

[15] M. Hasby, S. Hendriani and S. Indrarti, "Pengaruh Konflik Kerja, Beban Kerja dan Komunikasi Terhadap Stres Kerja Perawat Bagian Rawat Inap (Pada RSUD Petala Bumi Pekan Baru)," Jurnal Online Mahasiswa Fakultas Ekonomi Universitas Riau, vol. 4, no. 1, 2017.

[16] D. Suresh, Quality of Nursing Work Life among nurses working in selected government and private hospitals in Thiruvananthapuram. Kerala: Achutha Menon Center for Health Science Studies SreeChitraTirunal Institute for Medical Sciences \& Technology Thiruvananthapuram, 2013

[17] J. Prihastuty, N.A. Damayanti and Nuhospitalalam, "Increased Mode Quality Of Nursing Work Life To Lose Intention To Quit Nurses Premier Hospital Surabaya," Nurses Journal, vol. 8, no. 2, pp. 349-356 2013.

[18] S.B. Thakre, SS. Thakre and S.N. Thakre, "Quality of nursing work life Working At Tertiary Health Care Institutions: A Cross Sectional Study," International Journal Of Public Health And Community Medicine Thakre Sb Et Al. Int J Med Public Health Community, vol. 4, no. 5, pp. 1627-1636, 2017.

[19] H. Purnomo, "Recommendation Development QWL (Quality of Work Life) Based on QWL Influence Analysis on Job Satisfaction Leprosy Hospital Nurses in SumberglagahPacetMojokerto," J. Adm. PolicyKesehat., vol. 10, no. 3, pp. 129-136, 2012.

[20] F. Roshangar, R. Agheli, K. Parvan, P. Sarbakhsh, S. Shafeh and M Gholipur, "Orgational Citizenship Behaviors and Quality of Work Life," Pharmacophore, 2017

[21] T. Moradi, F. Maghaminejad and I. Azizi-Fini, "Quality Of Working Life Of Nurses And Its Related Factohospital," Nursing And Midwifery Studies, vol. 3, no. 2, 2014.

[22] W.N.K. Sari, "Relationship Between Quality of Work Life Job Satisfaction NursesNurse With patient wards of hospitals AM ParikshitTenggarong," The manuscript publication The science of nursing Program Muhammadiyah College of Health Sciences, 2017,

[23] N. Kholik, "Effect of Quality of Work Life and Organizational Commitment Against Competence Job Satisfaction With Mediation,' Study on Nurse Regional Public Service General Hospital KajenPekalongan, 2016

[24] S. Samtica, Hubungan Komponen Kualitas Kehidupan Kerja (Quality of Work Life) Dengan Motivasi Kerja Perawat Pelaksana di RS Haji Jakarta tahun 2011. Jakarta: Universitas Indonesia, 2011.

[25] H. Eren, and F. Theirar, "Quality Of Work Life By Nurses And Their Perceived Organizational Commitment Level," International Journal of Human Sciences, vol. 13, no. 1, pp. 1123-1132, 2016. 